\title{
IV. On the declination of the principal fixed stars, as observed at Greenwich in the year 1822
}

\section{Professor Bessel}

To cite this article: Professor Bessel (1825) IV. On the declination of the principal fixed stars, as observed at Greenwich in the year 1822, Philosophical Magazine Series 1, 66:327, 33-41, DOI: $10.1080 / 14786442508673918$

To link to this article: http://dx.doi.org/10.1080/14786442508673918

册 Published online: 10 Aug 2009.

Submit your article to this journal $\lceil\pi$

Џ Article views: 2

Q View related articles $\asymp$ 
M. Bessel on the Declination of the principal Fixed Stars. 33

bellato subpedali nudo, medio et supernè subbibracteolato, umbellâ repetito-trichotomâ, seu trifidâ corollis ferè ut in Cot. orbiculari, at pallidioribus." Wherefore the specific name of comscans, being one that misleads, is here changed to that of canalifolia. C. (channel-leaved farinose.)

rhombifolia. C. (rhomb-leaved farinose) farinoso-alba: foliis 9. approximatis obovato-rhombeis mucronatis : caule ramoso valido decumbente.
Habitat C. B. S.
G. $h$.

Communicavit amicus Parmentier A.D. 1823.

Obs. Cotyledoni hemisphæricæ proxima at magis ramosa, longè humilior, foliis minoribus supernè non ampliatis in arcum, sed rhombeis, magisque acuminatis; margine à medio ad apicem (cum mucrone) eleganter (aëre aperto) purpurascentibus. Flores non vidi.

Classis et Ordo. Dodecandria Trigynia.

Euphorbia, Linn. \& c.

grandidens. E. (rosy-spined triangular) aculeata erecta : 10. ramis simplicibus triquetris marginibus grandidentatis, dentibus bispinosis, spinis validis divaricantibus.

Habitat C. B. S. ubi invenit assiduus Bowie. G. H. 々 . Viget in Regio Horto Kewense. Erecta firma (nunc bipedalis), ætate teretiuscula, ramis simplicibus confertis in superiore parte plantæ, at mox fortè deciduis. Aculei validi subdivaricantes lætè rosei (morientes nigri) subbilineares infra foliolos orientes. Foliola ut in affinibus exigua, plana subtriangularia sessilia viridia lineam longa.

Species insignis, locanda pone $E$. lacteam. Flores non vidj.

IV. On the Declination of the principal Fixed Stars, as observed at Greenwich in the Year 1822. By Professor BEsseL*.

THE degree of perfection obtained by the observations at Greenwich, from the plan (adopted since 1821) of observing with the mural circle not only the stars themselves, but also their reflections from a horizontal surface, makes an

* From Schumacher's Astronomische Nachriehtcn, No. 73.

Vol. 66. No. 327. July 1825.

$\mathrm{E}$

exact 
exact comparison of those results with my own so interesting, that I have long formed the desire of applying to Mr. Pond's original observations the same method of calculation which I applied to my own. Taking therefore advantage of the numerous observations (direct as well as reflected) contained in the volume of 1822 , obligingly sent to me by $\mathrm{Mr}$. Pond through the kind intervention of Dr. Tiarks, I requested M. Olufsen, who is now here, to assist me in their reduction. I now communicate the results of these labours to the lovers of astronomy, since the explanation which they give, respecting the difference between Mr. Pond's standard catalogue and mine, is calculated to establish the true state of the case.

M. Olufsen has reduced all the observations of the polestar and fundamental stars made with the six microscopes, to the beginning of 1822, by means of the Königsberg table of refraction, and Professor Schumacher's Ephemerides.

The pole-star has been observed by direct vision, at 123 upper and 14.4 lower culminations; and by reflection, with 27 upper and 45 lower ones. Those direct observations, at both culminations, which could be advantageously combined for finding the declination of the pole-star, have given the correction of my tables, deduced from Mr. Pond's determinations in 1813, with the weight of 192 observations, $=-0^{\prime \prime}, 35$; agreeing to within one hundredth of a second with my determination, in part vii. of my Observations, page xxiv. After having corrected the declinations contained in Schumacher's tables, by $-0^{\prime \prime}, 35$, we calculated, from the direct observations of this star, the places of the pole upon the instrument; and then the mean, taken out of every ten successive observations, contained in the following table, with the corresponding days:

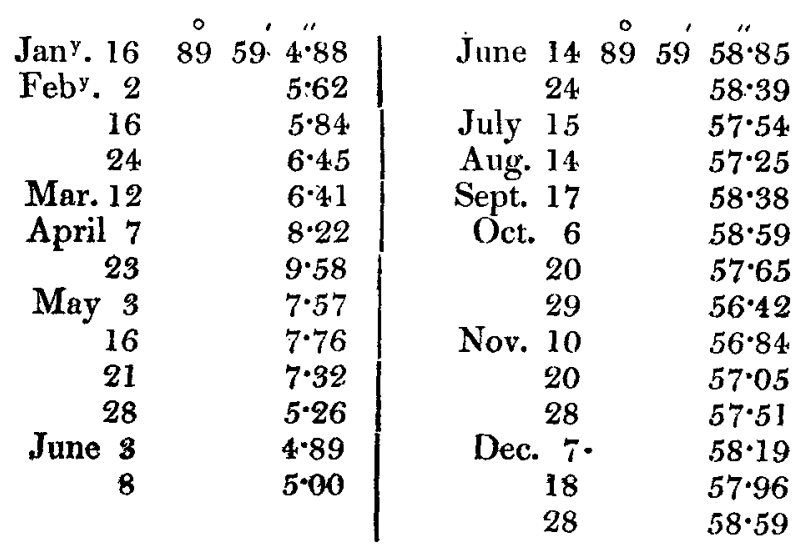


Fixed Stars, as observed at Greenwich in the Year 1822. $\$ 5$

The result of this table is, that the apparatus (probably the pillar to which the microscopes are fastened) was not quite unchangeable; for which reason the places of the pole, for those days not contained in the table, have been determined by interpolation. By means of this table, 72 observations by reflection of the pole-star showed the distance of the reflected from the true pole $=257^{\circ} 2^{\prime} 43^{\prime \prime}, 13$, after the reduction of the vessel containing the quicksilver (assumed at 5 feet 4 inches below the centre of the instrument) to the instrument. The results of the other stars are contained in the following table:

\begin{tabular}{|c|c|c|c|c|}
\hline & Direct. & & Reflected. & \\
\hline$\alpha$ Aurigæe & $4 \stackrel{\circ}{4} 11^{\prime} 41{ }^{\prime \prime} 72$ & 64 & $212^{\circ} 51 \quad \ddot{1} \cdot 76$ & 11 \\
\hline$\alpha$ Cygn & $4521 \quad 5 \cdot 66$ & 67 & $\begin{array}{lll}211 & 41 & 37.03\end{array}$ & 38 \\
\hline$\alpha$ Lyr & $\begin{array}{lll}51 & 22 & 35 \cdot 45\end{array}$ & 74 & $\begin{array}{lll}205 & 40 & 8 \cdot 26\end{array}$ & 50 \\
\hline$\alpha$ Geminor: & $\begin{array}{lll}57 & 43 & 52 \cdot 84\end{array}$ & 58 & $\begin{array}{lll}199 & 18 & 50 \cdot 79\end{array}$ & 8 \\
\hline & $\begin{array}{lll}61 & 33 & 9 \cdot 90\end{array}$ & 57 & $\left|\begin{array}{lll}195 & 29 & 34 \cdot 69\end{array}\right|$ & 4 \\
\hline$\beta$ Tauri . & $\begin{array}{lll}61 & 33 & 10 \cdot 74\end{array}$ & 46 & $\mid \begin{array}{lll}195 & 29 & 31 \cdot 53\end{array}$ & 5 \\
\hline a Andromed. & $\begin{array}{llll}61 & 53 & 32 \cdot 72\end{array}$ & 18 & $\left|\begin{array}{lll}195 & 9 & 9 \cdot 35\end{array}\right|$ & 10 \\
\hline$\alpha$ Coronæ & $\begin{array}{lll}62 & 40 & 49 \cdot 87\end{array}$ & 29 & $\mid 194: 21 \quad 53 \cdot 19$ & 18 \\
\hline$\alpha$ Arietis . . & $\begin{array}{lll}67 & 23 & 1 \cdot 53\end{array}$ & 46 & $\left|\begin{array}{lll}189 & 39 & 40.23\end{array}\right|$ & 18 \\
\hline$\alpha$ Bootis & $\begin{array}{lll}69 & 53 & 11 \cdot 41\end{array}$ & 86 & $\begin{array}{lll}187 & 9 & 30.52\end{array}$ & 34 \\
\hline$\alpha$ Tauri. . & $\begin{array}{lll}73 & 51 & 26 \cdot 03\end{array}$ & 61 & 183 II $15 \cdot 88$ & 8 \\
\hline$\beta$ Leonis . . & $\begin{array}{lll}74 & 25 & 59 \cdot 93\end{array}$ & 16 & $\mid \begin{array}{lll}182 & 36 & 44.03\end{array}$ & 17 \\
\hline$\alpha$ Herculis & $\begin{array}{lll}75 & 23 & 56.97\end{array}$ & 18 & $\begin{array}{lll}181 & 38 & 44 \cdot 89\end{array}$ & 13 \\
\hline * Pegasi & $\begin{array}{lll}75 & 45 & 1.03\end{array}$ & 27 & $\begin{array}{lll}181 & 17 & 40 \cdot 25\end{array}$ & 20 \\
\hline$\gamma$ & $\begin{array}{lll}75 & 48 & 22 \cdot 30\end{array}$ & 9 & $\left|\begin{array}{lll}181 & 14 & 19 \cdot 57\end{array}\right|$ & 8 \\
\hline a Leonis . . & $\begin{array}{lll}77 & 9 & 58 \cdot 77\end{array}$ & 48 & $\mid \begin{array}{lll}179 & 52 & 42.99\end{array}$ & 15 \\
\hline$\alpha$ Ophiuchi. & $\begin{array}{llll}77 & 18 & 8 \cdot 90\end{array}$ & 21 & $17944.34 \cdot 72$ & 12 \\
\hline$\alpha A$ & $\begin{array}{lll}81 & 35 & 40 \cdot 05\end{array}$ & 61 & $\left|\begin{array}{lll}175 & 27 & 2 \cdot 66\end{array}\right|$ & 43 \\
\hline$\alpha C$ & $\begin{array}{lll}82 & 38 & 6.32\end{array}$ & 52 & $174,24,34 \cdot 80$ & 6 \\
\hline pentis. & $\begin{array}{llll}83 & 0 & 27 \cdot 45\end{array}$ & 34 & $174 \quad 2 \quad 16.64$ & 15 \\
\hline$\beta$ Aquilæ . & $84 \quad 150.61$ & 9 & & - \\
\hline$\alpha$ Canis min. & $84 \quad 19 \quad 35 \cdot 65$ & 60 & $\mid \begin{array}{lll}172 & 43 & 7.71\end{array}$ & 7 \\
\hline$\alpha C$ & $\begin{array}{lll}86 & 36 & 51 \cdot 28\end{array}$ & 35 & - & - \\
\hline$\alpha$ Aquarii. & $91 \quad 10 \quad 49 \cdot 35$ & 33 & $\begin{array}{lll}165 & 51 & 52 \cdot 87\end{array}$ & 15 \\
\hline$\alpha$ Hydræ & $\begin{array}{lll}97 & 53 & 30.84\end{array}$ & 15 & $\mid \begin{array}{lll}159 & 9 & 12 \cdot 28\end{array}$ & 9 \\
\hline$\beta$ Orionis. & $\begin{array}{lll}98 & 24 & 53.81\end{array}$ & 11 & - & - \\
\hline$\alpha V$ & $100 \quad 13 \quad 44 \cdot 26$ & 25 & $\mid \begin{array}{lll}156 & 48 & 58 \cdot 69\end{array}$ & 23 \\
\hline $2 \alpha$ Capric. & $\begin{array}{lll}103 & 5 & 18 \cdot 99\end{array}$ & 26 & -1 & 一 \\
\hline $1 \propto$ Libræ & 10515 & 8 & $151 \quad 47 \quad 39 \cdot 36$ & 7 \\
\hline $2 \alpha-\ldots$ & $\begin{array}{lll}105 & 17 & 45.02\end{array}$ & 4 & $\left|\begin{array}{lll}151 & 44 & 57 \cdot 71\end{array}\right|$ & 2 \\
\hline naj. & $\begin{array}{lll}106 & 28 & 45.90\end{array}$ & 59 & $150 \quad 33 \quad 58^{\circ} 42$ & 7 \\
\hline$\alpha$ & $\begin{array}{lll}116 & 1 & 38.92\end{array}$ & 15 & $141 \quad 1$ & 7 \\
\hline tous. & $\begin{array}{llll}20 & 33 & 45 \cdot 49\end{array}$ & 0 & & $=$ \\
\hline
\end{tabular}

E 2 
Assuming that the readings of the instrument require a correction for the effect of gravity upon it, of the form

$a \sin z+b \cos z$

in which $z$ signifies the distance from the zenith (reckoning from 0 to $360^{\circ}$ from the zenith to the south), we obtain from the measured distance $\mathbf{P}$ of a star from the pole, its declination

$\delta=90^{\circ}-\mathrm{P}-(a \cos \phi-b \sin \varphi)-a \sin (\phi-\delta)-b \cos (\phi-\delta)$ and from the reflected image,

$\delta=\mathrm{P}+2 \phi-270^{\circ}+a \cos \phi-b \sin \varphi+a \sin (\varphi-\delta)-b \cos (\phi-\delta)$

The result of the combination of the two formulæ is

$360^{\circ}-2 \phi=\mathrm{P}+\mathrm{P}^{\prime}+2(a \cos \phi-b \sin \phi)+2 a \sin (\phi-\delta)$

Or, by putting the latitude of Greenwich,

$$
\phi=51^{\circ} 28^{\prime} 39^{\prime \prime}+y \text { and } \mathrm{P}+\mathrm{P}^{\prime}=257^{\circ} 2^{\prime} 42^{\prime \prime}+m
$$

we have $0=m+2(y+a \cos \phi-b \sin \phi)+2 a \sin (\phi-\delta)$

$$
=m+2 x+2 a \sin (\phi-\delta)
$$

where $x$ is written for $y+a \cos \phi-b \sin \phi$.

The following are the equations which result from the different stars :

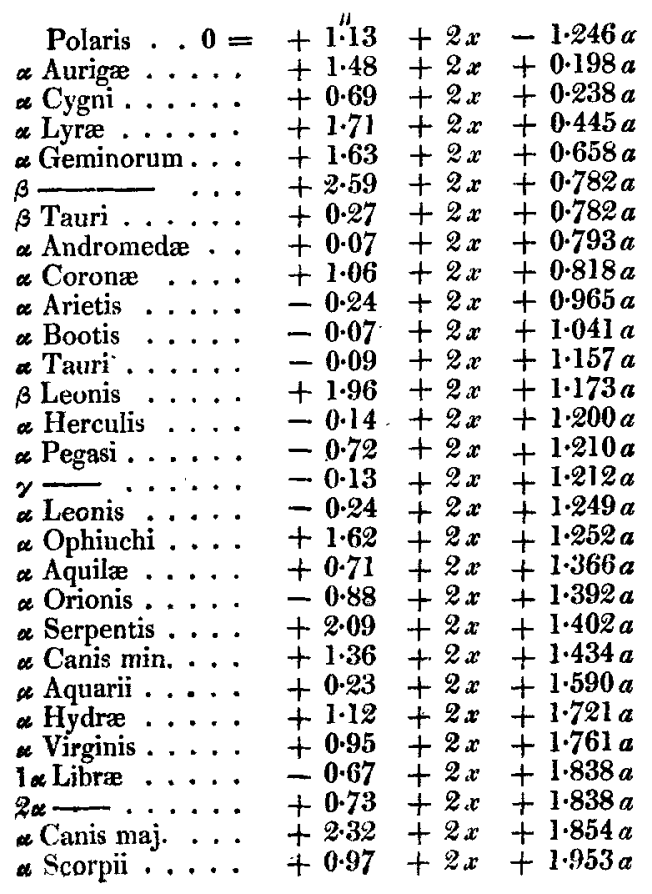


Hence it follows that the value of $a$, in the Greenwich instrument, must be very small. Mr. Pond, indeed, considers it as vanishing altogether. However, by keeping entirely to the observations, and resolving the above 29 equations after the method of minimum squares, we shall find

$$
a=+0^{\prime \prime}, 239 \text {, and } x=-0^{\prime \prime}, 5082
$$

and hence the latitude is

$51^{\circ} 28^{\prime} 39^{\prime \prime}+x-a \cos \varphi+b \sin \phi=51^{\circ} 28^{\prime} 38^{\prime \prime}, 3429+0^{\prime \prime}, 786 b$

in which the dependence of the last term on $b$ could have been removed only by reversing the instrument; a measure however which, by its construction, is rendered impracticable. In order that we may resolve this calculation effectually, I have first determined the probable error of the direct observations, as well as of those of the reflected ones. I find the same result for the former, out of 412 , and for the latter out of 265 observations, viz. $\pm 0^{\prime \prime}, 799$. Whence it appears, that Mr. Pond must have secured the vessel containing the quicksilver from every kind of concussion, since the probable error of the observations by reflection has not been in the least increased. From this equality of value by both methods of observation, each of the above equations (resting upon $a$ observations by direct vision, and $a^{\prime}$ observations by reflection) give the weight $a a^{\prime}:\left(a+a^{\prime}\right)$. According to this weight I have made the calculations. The coefficient of the sine of the zenith-distance has received the weight of 366 observations.

According to the formulæ above mentioned the declination of a star is, from the direct observations,

$=90^{\circ}-\mathrm{P}-0^{\prime \prime}, 1489-0^{\prime \prime}, 239 \sin (\phi-\delta)+b[\sin \varphi-\cos (\phi-\delta)]$ and from the observations by reflection

$=\mathrm{P}^{\prime}-167^{\circ} 2^{\prime} 42^{\prime \prime}, 8653+0^{\prime \prime}, 239 \sin (\varphi-\delta)+b[\sin \varphi-\cos (\varphi-\delta)]$

Hence it follows that the bend of the instrument, depending on $b$, can be as little eliminated as in the determination of the latitude: whence nothing remains but to neglect it altogether. For $\delta=2 \phi-90^{\circ}=+12^{\circ} 57^{\prime}$ it has no influence on the declination; for northern declination its coefficient is negative; for southern, positive. The declinations resulting from the direct observations and those by reflection, under the assumption of $b=0$, as well as to the mean taken with respect to the number, is contained in the following table: 


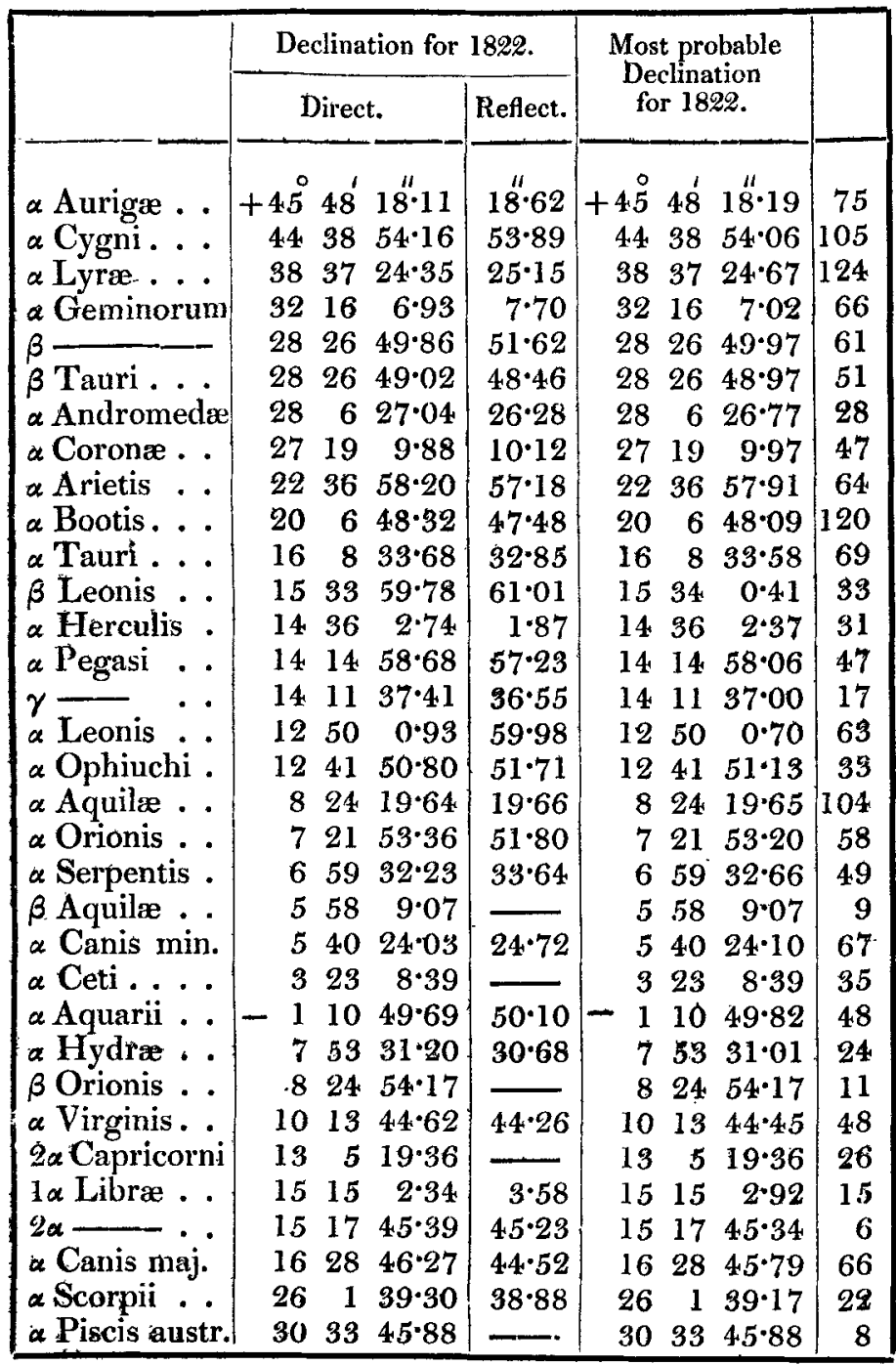

The declinations contained in the last column can, on account of their having been calculated with the Königsberg table of refraction, be immediately compared with my catalogue. The following table shows their differences from my declinations, as well as the differences of Mr. Pond's standard catalogue and his list for 1822 (Astron. Nachr. No. 28), by which the changes which these differences have gradually undergone may be seen at once: 
Fixed Star's, as observed at Greenwich in the Year 1822. 39

\begin{tabular}{|c|c|c|c|}
\hline & $\begin{array}{c}\text { Standard } \\
\text { Catalogue. }\end{array}$ & $\begin{array}{l}\text { Pond } \\
1822 .\end{array}$ & $\begin{array}{l}\text { New Cal- } \\
\text { culation. }\end{array}$ \\
\hline 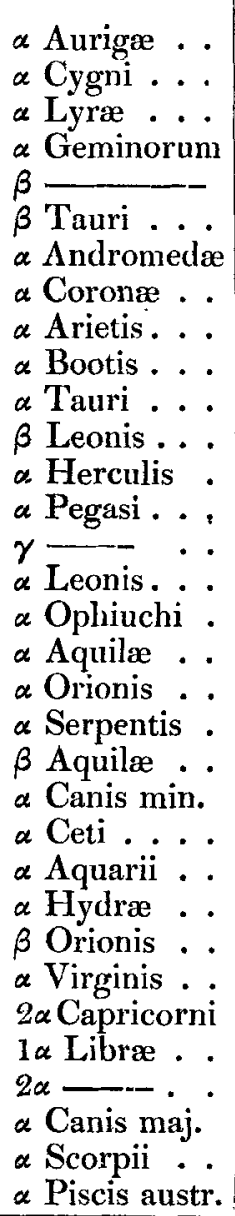 & $\begin{array}{l}+11 \\
+2 \cdot 88 \\
+2 \cdot 39 \\
+2 \cdot 05 \\
+1 \cdot 57 \\
+2 \cdot 02 \\
+3 \cdot 15 \\
+2 \cdot 71 \\
+2 \cdot 69 \\
+2 \cdot 45 \\
+2 \cdot 54 \\
+2 \cdot 09 \\
+3 \cdot 18 \\
+4 \cdot 13 \\
+2 \cdot 98 \\
+2 \cdot 61 \\
+3 \cdot 27 \\
+3 \cdot 43 \\
+3 \cdot 60 \\
+3 \cdot 24 \\
+4 \cdot 39 \\
+4 \cdot 22 \\
+3 \cdot 15 \\
+4 \cdot 19 \\
+3 \cdot 54 \\
+3 \cdot 15 \\
+3 \cdot 16 \\
+5 \cdot 35 \\
+6 \cdot 66 \\
+4 \cdot 65 \\
+5 \cdot 16 \\
+5 \cdot 74 \\
\end{array}$ & 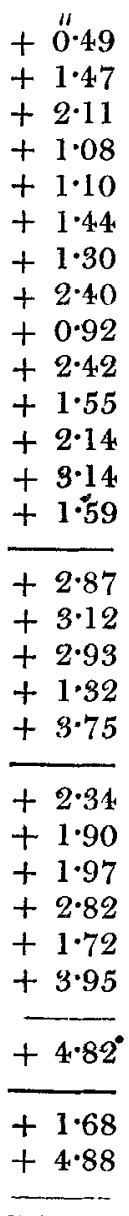 & $\begin{array}{l}+0.13 \\
+0.46 \\
+0.97 \\
+0.36 \\
+0.61 \\
+1.16 \\
+0.27 \\
+0.49 \\
+0.89 \\
+0.67 \\
+0.72 \\
+0.54 \\
+1.14 \\
+0.49 \\
+0.73 \\
+1.74 \\
+1.71 \\
+0.95 \\
+0.01 \\
+1.40 \\
+1.25 \\
+1.26 \\
+1.74 \\
+1.27 \\
+1.22 \\
+0.74 \\
+1.29 \\
+2.90 \\
+1.15 \\
+0.45 \\
+0.33 \\
+1.12 \\
+5.13\end{array}$ \\
\hline
\end{tabular}

On comparing this list, we find that the differences of the new calculation and the Königsberg catalogue are both smaller and more uniform, than the difference of the two Greenwich catalogues compared with one another. The reason of the greater regularity seems to lie partly in the more correct reductions which are, without any trouble, obtained by Schumacher's tables, and partly in the application of more accurate corrections of the refraction caused by the state of the thermo- 
meter; in which Bradley's rule perceptibly deviates from the truth. The regularity hereby obtained is of about the same magnitude as the probable errors would lead us to expect. The reason of the greater deviation at $2 \alpha$ Capricorni is unknown to me; that of $\alpha$ Piscis austr. may arise from the centre of the long coloured spectrum (which this lowly culminating star presents) having been differently determined by two different observers.

The constant difference of both series of observations has been so greatly diminished by this calculation, that it is no longer so striking as before. But, whilst the casual errors of the single observations are reduced to a trifle, by the increase of their number, the goodness of the instruments, and the care in their use, the imperfections of the elements of reduction, hitherto unnoticed, distinctly appear. If, after the increased certainty of Mr. Pond's observations (by the application of the method of observing by reflection), the difference were still as great as in the standard catalogue, yet we should be led to believe that there are other unknown sources of error. Now, however, I think I am ahle to point out some circumstances which might account for differences of this magnitude.

If, for instance, we were to increase the logarithms of the Greenwich refractions by about 0.0035 (which for $45^{\circ}$ of zenith distance amounts to $0^{\prime \prime}, 4.7$ ), the differences would become partly positive, partly negative. Such a change would lead us to suppose that either the barometer stands 0.24 inches too low, or the thermometer $4^{\circ}$ Fahrenheit too high. Or, distributing the error on both, that the first is 0.12 inch too low, and the second $2^{\circ}$ too high. We might add that the sense in which both errors must be assumed, is agreeable to former experience: for the barometers often stand too low, owing to air having been introduced by long use, or to the bore of the tube not being corrected by the scale; respecting which I find no notice with reference to the barometer of Greenwich. The height of my barometer, for instance, would be 1 line $=0.09$ inch (English) too short, if I were to use them without correction: the freezing point also of the thermometer moves upwards in time; although I do not think that changes of this kind, exceeding $1^{\circ} \mathrm{Fahr}$., have ever been observed. If $\mathrm{Mr}$. Pond would be so kind as to give some account of the condition of his meteorological instruments, we should be able to decide at once, whether any difference, and how much thereof, is to be ascribed to this cause. I might readily have determined the constant of refraction, from Mr. Pond's observations (which would have removed every doubt concerning the meteorological instruments) had there been among the lower culminations, 
culminations, in the observations for 1822 , any that had been fit for it. The volume for 1821 I have not yet seen; and to employ earlier ones $I$ consider unadvisable, since it is probable that the instrument now gives quite different polar distances from what it used to do.

However, I am not of opinion that an imperfection in the meteorological instruments is absolutely necessary for the explanation of the difference between the two series of observations: on the contrary, I believe that this difference may be also explained from the supposition already made, - that the bend of the instruments is such as may be removed by the application of counterpoises invariable in all situations relative to the horizon. From this supposition follows the formula $a \sin z+b \cos z$. However, I have reason to think that this ground may be essentially erroneous, which I intend to explain in another place.

For the present, the question respecting the difference between the Greenwich and Königsberg observations sems to me to stand thus :

$1^{\circ}$. That there can be no doubt but that the mural circle at Greenwich (probably by the strengthening of the telescope undertaken in 1821) has now given larger polar distances than before; as is proved by the catalogues of 1813 and 1822 .

$2^{\circ}$. That the difference has been so far reduced from the perceptible magnitude, which it had according to the standard catalogue (partly by Mr. Pond's own subsequent catalogue, partly by M. Olufsen's calculation of the observations of 1822 , made after my refractions), that the remaining part may be readily explained from very probable causes.

BESSEL.

V. On the Construction of the large Refracting Telescupe just completed. By M. Fraunhorer. Read at a Meeting of the Royal Bavarian Academy of Sciences, the 10th of July 1824*.

THE instrument, of which I have the honour of speaking, is destined for the Imperial Observatory at Dorpat. It is the largest of its kind, and new in various parts of its construction.

The largest telescopes hitherto used were those constructed with metal mirrors. But since even the most perfect of these mirrors reflect but a small portion of the light it receives (the larger portion of it being absorbed), the mirror telescopes must

* From Schumacher's Astron. Nachrichten, Nos. 74 and 75.

Vol. 66. No. 327. July 1825. 